\title{
Improving EFL Students' Speaking Proficiency and Motivation: A Hybrid Problem-based Learning Approach
}

\author{
Mohamed Ali Mohamed Kassem \\ Department of Curriculum and Teaching Methodology, Faculty of Education in the New Valley, Assiut University, \\ Egypt
}

\begin{abstract}
The present study used a Hybrid Problem-Based Learning (H-PBL) approach for teaching a Speaking Course to the First-Year students of the English Department at Prince Sattam Bin Abdulaziz University, Saudi Arabia. Previous research has proved the currently inappropriate teaching approaches and the lack of motivation to be the most significant reasons for EFL students' poor speaking proficiency. The lack of motivation is due to the traditional, rigid and tedious teaching techniques adopted in speaking classrooms and partly due to the standardized curriculum of the speaking course where there is no scope for instructors to change their teaching approach or introduce new ideas in the curriculum. The H-PBL approach has been proved to be an effective model for teaching language skills; however, the existing literature still lacks an actual action plan or a methodology to introduce this approach as a pedagogical remedy for motivating EFL students and improving their speaking proficiency. The study addressed this gap by recommending the use of H-PBL approach in EFL speaking classes. The study used a pre-post speaking proficiency test, a students' motivation questionnaire, interviews and observation sheets as data collection tools. Results revealed that the H-PBL approach has a positive effect on improving the students' speaking proficiency, students' motivation significantly increased and, eventually, students tended to be more self-directed and independent. Instructors also applauded the use of H-PBL approach but recommended adapting the curriculum and the teaching strategies to support this approach.
\end{abstract}

Index Terms - H-PBL, speaking proficiency, motivation, teaching strategies

\section{INTRODUCTION}

Speaking is a major language skill that EFL learning programs have sought to develop to enable students to express their ideas appropriately and to communicate successfully. Speaking proficiency has become evidence that learning a language is achieved (Glover, 2011). However, speaking is considered the most challenging skill in mastering a language because of its spontaneous nature and the implementation of conventional teaching approaches that emphasize memorization and students' passive role (Shabani, 2013). On the contrary, research has revealed that improving speaking proficiency requires students' vigorous involvement in the learning process and a supportive environment that triggers students' motivation.

In response to the calls for involving students in the learning process, various approaches and methods based on the constructivist approach of learning are being adopted, such as Project-Based Learning, Task-Based Learning, Cooperative-Learning and Problem-Based Learning (PBL) (Amma, 2005; Juvova et al, 2015). These methods have been developed as a reaction to memorization or rote-learning as well as to teacher-centered approaches that focus only on the transmission of knowledge from teachers to students. PBL, the focus of the present study, is believed to be suitable for current EFL settings because students, through this approach, find an opportunity to communicate, work together and collaborate to solve complicated and authentic problems. This approach has been proved to motivate students' learning process and facilitates the acquisition of language skills $(\mathrm{Li}, 2013)$. Moreover, it is claimed that PBL approach has the potential to help students with poor language skills as it has been an effective teaching approach used for enhancing productive skills in very difficult situations (Lian, 2013).

PBL has gained much currency among educators not only as a teaching approach but also as a radical philosophy that seeks to change the theory of teaching and learning (Bueno et al, 2015). It is described as the most outstanding educational innovation in the 20th century (Jonassen, 2011). In this regard, the strength of the PBL approach resides in the following points: (1) relying on a reliable theory in the field of cognitive psychology; (2) calling for an active and central role of students; (3) minimizing the over-dominant role of instructors; (4) advocating self and peer assessment instead of teacher's assessment; (5) fostering students' critical and creative thinking; (6) relating learning to real world problems; and (7) enhancing students' motivation (Savery, 2006).

The main objectives of PBL approach are to structure new knowledge by creating an environment in which students can employ their previous knowledge with the one acquired during their problem-solving sessions (Barrell, 2007), to develop flexible and extensive knowledge, to foster the acquisition of problem-solving and reasoning skills (Uden \& 
Beaumont, 2006), and to support autonomy and self-directed learners who rely on their intrinsic motivation (Hmelo et al, 1994). In other words, in the PBL approach, real learning takes place when learners practice problem-solving skills and develop their language skills. PBL approach was first introduced at McMaster University as an experiment model to evaluate whether learning acquired in school was relevant to future career (Barrows, 1986). With the implementation of the PBL approach, students were required to first identify problems and then attempt to resolve them through inquiry and exploration. This necessitated that they learn key concepts and strategies necessary for resolving problems.

$\mathrm{Wu}$ (2006) illustrates that the PBL approach can be implemented in full and in a hybrid or guided mode. The former type requires students to define the problem through exploration and understanding the scenario; to learn on their own, with teacher only facilitating and prompting them to give further clarification and explanation. No lectures are given by the teacher. Eventually, students are required to work independently to offer best solutions to the problems under study and justify them. On the other hand, the hybrid mode, first introduced in Harvard Medical School (Armstrong, 1991), takes a case-based approach wherein the teacher presents the problem case-scenario contextually, delivers lectures to explain basic concepts, defines its theoretical perspectives and divides students into groups requested to determine the problem(s) based on the facts, identify the issues and propose the best solutions based on their newly acquired knowledge and skills.

The H-PBL approach is based on constructivism which postulates that learners' attitude, behavior and overall learning are based on their prior knowledge. According to Gijbels and Loyens (2009), constructivism considers learning the ultimate outcome of the interaction between learner's current knowledge and new experiences acquired by the learner from the environment. Thus, the constructivists adopt a student-centered learning approach in which students are actively involved in a process of new knowledge construction (Liang \& Gabel, 2005). Similarly, Ben-Ari (2001) observes that, in order to construct new ideas or concepts and to pave the way for real interaction with prior knowledge, a learner must be involved consistently into an act of mental balancing instead of obtaining information directly from the teacher. In this regard, learning environment plays a major role as it allows the learners to gain learning experiences (Taber, 2000), to retain learning and to improve problem-solving, critical and creative thinking skills (Neo \& Neo, 2009). On the contrary, the constructivist approach is often criticized for minimizing the role of the teacher in the learning process to guiding students throughout the learning process and creating a supporting learning environment to enable them to construct knowledge.

Exploring what a student is expected to do in a H-PBL approach is of paramount significance. According to Jaleniauskiene (2016), the H-PBL approach requires that the individual student should participate actively in his own learning and undertake the responsibility for identifying his or her learning needs and achieving the desired outcomes. Simultaneously, the students are expected to use the H-PBL approach with interdisciplinary, additional learning resources and apply measures, such as critical thinking, fun learning experiences or any contextualized issues to understand and gain knowledge, thus introducing the concept of hybridity (Norman \& Schmidt, 1992). Being interdisciplinary in nature and by introducing the concept of hybridity, this approach also allows a simultaneous development of analytical and professional skills in the learners, which is difficult to achieve with conventional teaching methods.

In conclusion, the study aimed at investigating how the H-PBL approach can be utilized to create a learning environment that will not only facilitate the improvement of students' speaking proficiency but can also result in positive changes in their motivation too.

\section{A. Problem of the Study}

It has been observed that the majority of English majors at Prince Sattam bin Abdulaziz University encounter difficulties such as poor speaking skills, reluctance to participate in conversation, fear of committing errors, lack of confidence, and lack of English speaking peers or social circles, which can help them to hone their speaking potential. In addition, most of the students are passive recipients of data as they take no initiative in participating in activities, such as English club, seminars, language workshops which are intended for the enhancement of their speaking proficiency.

Another aspect of the problem is that Saudi EFL students are less motivated to learn English (Alfawzan, 2012; Alajmi, 2014; Aslam, 2014; AlKaabi, 2016). All these studies are unanimous that Saudi EFL students' lack of motivation for learning English is due to the traditional teaching approach that prepares learners only for mid/end term examination and the learning outcomes are test-oriented rather than cognitive. The current teaching practices pay much attention to grammatical rules, rote learning or memorization, translation of texts to facilitate teaching of skills courses without being concerned with students' motivation for learning English. Moreover, students' low motivation has a negative effect on their academic achievement in speaking tests (AlKaabi, 2016).

Given all the aforementioned practices, there is a need to change the teaching practices in speaking classrooms. The researcher argues that the $\mathrm{H}-\mathrm{PBL}$ approach rather than the traditional lecture-based approach is more pertinent to resolving the issues. However, this would not be an easy task due to a few challenges and constraints. The H-PBL approach would require a longer duration to prepare lecturers and lab sessions; instructors need to be trained on the implementation of this approach, particularly its methods of delivery and post-teaching assessments; the students, too, have no exposure to this new approach as their past learning was based on the conventional approach during their high school. 


\section{B. Questions of the Study}

This study sought to address the following questions:

1- What is the effect of using a H-PBL approach on improving Saudi EFL students' speaking proficiency?

2- What is the effect of using a H-PBL approach on improving Saudi EFL students' motivation?

3- What are the teachers' and students' perceptions of using a H-PBL approach in teaching a speaking course?

\section{Hypotheses of the Study}

The study was based on the following hypotheses:

1- There would be statistically significant differences between the mean scores of the experimental group and the control group in the post-test of speaking proficiency in favor of the experimental group.

2-There would be statistically significant differences between the mean scores of the experimental group and the control group in the post-application of students' motivation questionnaire in favor of the experimental group.

\section{REVIEW OF LITERATURE}

\section{A. Students' Role versus Teacher's Role in PBL}

According to PBL, a student-centered approach, students take charge of their own learning whereas instructors assume the role of facilitators in an endeavor to: (1) scaffold students via modeling and active implementation of questioning strategies; (2) provide sufficient guidance to guarantee students' smooth progress in the different stages of PBL (3) monitor students' performance and exchange of their feedback; (4) encourage students' implementation of reasoning skills; and (5) decrease the amount of scaffolding when students display willingness to and competence in constructing their learning (Hmelo et al., 1994;Torp \& Sage, 2002). However, teachers face two serious challenges in implementing PBL. First, difficulty with constructing the problems as they should meet a number of criteria such as addressing students' interests, challenging students' thinking potentials, relating to students' real-life needs and serving as a means for meaningful communication (Larsson, 2001). Second, the target language is used as a means for discussing and solving the problems. This means that students should have sufficient language proficiency. Otherwise, students will be frustrated and demotivated.

\section{B. Using PBL to Improve Students' Motivation}

Reviewing previous studies shows that the PBL approach seeks to provide learners with more choices, autonomy and self-determination to keep them motivated (Mossuto, 2009; Li, 2013). For instance, Mossuto (2009) in his empirical study found out that using PBL in which learners studied in interactive groups and their learning depended on openended tasks was significant in triggering students' thinking throughout the learning process and keeping them highly motivated. Razzak (2012) introduced the PBL approach in an educational psychology course in Bahrain to identify the factors that cause students' lack of motivation. Data were collected by monitoring students' performance in group presentations. Findings showed high satisfaction with PBL and improvement in the learning outcomes. Similarly, Huang (2012) experimented PBL in EFL classrooms in order to examine its feasibility in real situations. Four variables were qualitatively investigated including students' attitude, satisfaction, motivation, and self-achievement. Findings revealed that students' attitude toward learning was positive and their motivation level was significantly high compared to the traditional group.

\section{Using PBL to Improve Speaking}

In EFL context, several studies were conducted to assess the effectiveness of the PBL approach in developing speaking skills (Ahlfeldt, 2003; Solaina, 2013; Rohim, 2014). Ahlfeldt (2003), for instance, examined the use of PBL approach in contrast with the traditional learning approach. Results of this study hinted that PBL was a more effective method of instruction as learners prepared better speeches than students who learn in traditional classrooms. It was also found out that students in PBL were involved in text and the course material that helped them to cope with their speaking anxiety, which was not the case in traditional classrooms. Rosalina (2013) implemented PBL approach in an EFL university speaking class in Indonesia. Her study revealed that the use of PBL not only improved students' speaking skills but also positively affected the other relevant components such as grammar, pronunciation, and vocabulary. Similarly, Rohim (2014) implemented PBL approach to improve speaking skills of a heterogeneous group comprising multiple nationalities. His research employed a mixed method approach using action, observation, and reflection during the experiment. The findings revealed a significant improvement in the students' speaking skills.

Finally, it seems that no study was conducted on the implementation of the H-PBL approach in EFL settings. This necessitates attempting this recommended teaching approach since much attention has been paid to students' active involvement in the learning process. This study, having taken into account the results of previous ones, aimed to fill the gap by exploring the possibility of implementing the H-PBL approach in the context of EFL speaking classroom and to examine how the H-PBL approach can be adopted to improve Saudi EFL students' speaking proficiency and to motivate them to learn English.

\section{METHOD}




\section{A. Research Framework}

The present study employed the H-PBL approach in teaching a speaking course to accomplish at least two main objectives derived from the problem under investigation. In other words, the two objectives were to improve EFL students' speaking proficiency and to find ways to motivate them for learning English. The major concern of the present study was to investigate the relationship between motivation and improvement of students' speaking proficiency. This is consistent with the arguments made by researchers that motivation is responsible for acquisition and development of language skills in EFL; more than a good curriculum and skilled and experienced instructors (Wang, 2008; Murphy \& Alexander, 2000; Dornyei, 2008; Li, 2013). Hence, improving students' speaking proficiency and motivation to learn English are the two main foci of this study. In addition, it was also necessary to investigate instructors' and students' perceptions of the H-PBL approach; this constitutes the third objective of this study.

\section{B. A Mixed-method Approach}

The present study used the mixed method approach whose two components, qualitative and quantitative, are combined to verify a judgment (Onwuegbuzie et al 2012). The study commenced with the quantitative approach by administering a pre-post test for both groups sampled for this study and proceeded to the qualitative approach, after setting the results of the quantitative analysis through a statistical assessment. The rationale for using the mixed mode is to be consistent with the recommendations of Teddlie and Tashakkori (2008) who confirmed that the use of the two methods concurrently will lead to more accurate results.

To recap then, the former phase, the quantitative phase, was dedicated to understanding the first two variables of the study, namely students' speaking proficiency and their motivation for learning English. In the latter phase, the qualitative approach was used for data collection through individual semi-structured interviews and class observations of the first phase as significant predictors of the usefulness of the H-PBL approach to study the three variables, including the instructors' perceptions of H-PBL approach. Hence, the former phase of this study was exploratory and adopted a quantitative approach while the latter phase was confirmatory of the new data and followed a qualitative approach. The mixed approach helped to avoid the so-called methodological monism, or using a single research method (Creswell, 2014).

\section{Sample of the Study}

This research employed a homogenous sampling strategy (Creswell, 2014) that enabled a purposeful, convenient sampling to identify respondents of the same membership of a subgroup having pre-defined characteristics. This sampling technique also assisted in the selection of the research site, that was, Prince Sattam Abdulaziz University, Saudi Arabia. The participants were selected based on several pre-identified characteristics; one case is that they must be EFL learners registered in the First Year of the English Degree Program since the speaking course is offered only at this level to all students of the English Dept. As a part of the protocol, all participants were asked to sign an approval form to guarantee that they were willing to participate in this research. In addition, the researcher demonstrated the objectives and the expected outcomes of this research. In short, sixty students from the English Department participated in the experiment, after having divided them into two equivalent groups (control vs experimental).

\section{Tools of the Study}

\section{Test of Speaking Proficiency (TSP)}

The test aimed at measuring the speaking proficiency of first year students at the Department of English, Prince Sattam bin Abdul Aziz University, Saudi Arabia. The TSP took the shape of oral presentations in which the participants' speaking proficiency was assessed through a set of criteria to determine whether the level of communication would improve after implementing the H-PBL approach. The assessment criteria included, besides speaking fluency, testing vocabulary and grammar structures, understanding what is asked, and adopting a pronunciation and intonation intelligible to speakers of the English language. Therefore, a 4-point rubric was developed for scoring the test (see Appendix A). Four criteria were used to assess students' speaking proficiency: (1) fluency, (2) pronunciation, (3) vocabulary and (4) grammar. Each criterion had a maximum score of four points; therefore, the maximum score for the test was 16 points. Two experienced professors volunteered to participate in scoring each student's speaking proficiency. They rated the student's speaking proficiency independently, using the scoring rubric designed by the researcher. Prior to the experiment, an orientation session on how to assess students' performance based on the rubric was conducted by the researcher. Inter-rater reliability was 0.89 , which indicates a high level of reliability. To determine content and face validity, the test and the 4-point scoring rubric were submitted to a panel of ten EFL experts whose comments and amendments were considered in the final version of the test. Thus, it was concluded that the test is a valid instrument for measuring the students' speaking proficiency.

\section{Students' Motivation Questionnaire (SMQ)}

To assess students' motivation, the researcher prepared a questionnaire that included 25 statements in its initial version. Students were requested to respond to each statement on a five-point Likert Scale, ranging from 1 (strongly disagree) to 5 (strongly agree). The questionnaire was submitted to a panel of experts to determine its suitability for measuring students' motivation. The questionnaire, in its final version, consisted of 20 items (see Appendix B). Thus, it is an approved, validated and appropriate tool for measuring students' motivation. The reliability of the SMQ was 
established via the test-retest method. In the pilot stage, the questionnaire was administered twice on a sample of 20 students excluded from the main sample of the study. There was a four-week interval between both administrations of the questionnaire. An Alpha Cronbach's correlation coefficient of 0.88 was calculated. Moreover, an internal consistency reliability check was computed and it was found that the alpha coefficient for the SMQ was 0.90.

III. Instructors' and Students' Interviews

Interviews with the participants and the instructors were carried out to investigate the instructors' and students' perceptions of using a H-PBL approach for teaching a speaking course and how the H-PBL approach was effective in improving the students' speaking proficiency. The open-ended questions were chosen to assess the students' and instructors' perceptions (see Appendix C). These qualitative interviews provided in-depth data about the informants' reflective experiences which could not be identified during their oral presentations.

\section{Procedures}

At the beginning of the first semester of the academic year (2017/2018), two classes of 30 students each were chosen. The first class employed the traditional approach of teaching the speaking course while the H-PBL treatment was applied in the second class. At the end of the semester, the two groups were post tested. Students were required to deliver presentations after the experiment was over. These students were also interviewed to explore the difficulties and anxieties they faced in learning the speaking course. In addition, instructors were also interviewed to obtain their feedback about EFL students' speaking proficiency and motivation and how far the implementation of H-PBL was effective in improving students' speaking proficiency.

The experiment commenced with conducting the pre-test on the two groups: Group A (traditional method of teaching) was the control group and Group B (H-PBL method of teaching) was the experimental group. To serve the purpose of this study, a model similar to the Edwin Bridges' Problem-Stimulated PBL (PSPBL) model (Bridges, 1992) was implemented in teaching the speaking course offered to the first-level students at PSAU, Saudi Arabia. Since the main goal of PSPBL was to develop domain-specific skills, this model suited the objectives of this study. This model helped the researcher to find various means to enhance Saudi EFL students' speaking proficiency, means that were far below expectations. Moreover, PSPBL was also a suitable model in the context of this study since students were not motivated to learn English and a need arose to use novel techniques for engaging the students.

According to this model, and pertinent to H-PBL approach, the lessons were presented in the form of a problem. In other words, each lesson took a case-based approach, following the original Harvard model (Armstrong, 1991), in which both the teacher and students understand problem contextually based on facts, define hypotheses and suggest best possible solutions through newly acquired learning. For example, Unit 2 of the Textbook dealt with Internet dangers and harmful effects of access to the Internet 24/7 and addiction of kids to laptops, tablets, smartphones, and game consoles. The students were asked to treat it as a problem and convert it into a case, formulate hypotheses, and find out solutions to reduce the chance of child victimization. The students conducted group discussions to understand the problem. It was quite clear that students used their prior knowledge as they brainstormed ideas into different hypotheses to explain the problem. During this activity, all students of the group were encouraged to speak. The researcher used such a model over the whole semester to teach all the units of the textbook. (Appendix D)

During teaching sessions, classroom observations were carried out by the teacher. The value of using observation was to give teachers an opportunity to see directly what students do rather than to rely on what they claim they can do (Dornyei, 2007). However, these observation sessions were more of a reflective assistance, not an evaluative tool (Yin, 2014). Then the researcher also informed the students in the follow-up interviews to comment on some of the learning incidents observed in their oral presentations, which helped frame the themes and sub themes of this study.

Throughout the semester, data were collected through oral presentations, semi-structured interviews and observations. The multiple tools enabled the researcher to perform a methodological triangulation of data in the end. All oral presentations and the interviews were recorded to prepare transcripts. The transcripts of both interviews and oral presentations used the analytical coding method (Linda, 2011) which necessitated reading and re-reading line-by-line to gain familiarity with the data. While reading the transcripts of both interviews and oral presentations, the data were coded into categories and themes using Miles and Huberman's (1994) Concurrent Flow Model which required reducing different types data not in linear manner but simultaneously as themes and sub-themes happening over and over again. This analysis enabled the researcher to draw relationships between data sources and make themes more visible and retrievable. Gradually, the data sources became saturated and themes and categories were more refined enabling the researcher to understand general patterns and relationships emerging from the data.

The process of thematic analysis is often directed by the grounded approach proposed by (Glaser \& Straus, 2006; Strauss \& Corbin, 1994) and is most suitable and informative particularly in the fields of educational and cultural research. Therefore, the thematic content analysis of the transcripts of students' oral presentations and interviews (instructors and students) was a useful primary data technique not only to assess how H-PBL approach motivated Saudi EFL students and improved their speaking proficiency but also to assist in assessing the instructors' and students' perceptions of the adoption of the H-PBL approach in contrast with the traditional approach. The method eventually helped the researcher to identify themes based on the categorization and clustering of the factors that were emerging from the transcripts from both groups. These themes were distributed in clusters and termed as pre-identified characteristics of the Saudi EFL students as they were the primary participants of this study. Last but not the least, the 
method helped the researcher to make a close examination of the perception of the participants in both groups as they experienced events in their "multiple contextual factors" (Creswell, 2102) with a constructivist approach and with participatory perspectives (Guba \& Lincoln, 1989). As the last step, findings were compared between group A (traditional approach) and group B (H-PBL approach) to examine how the H-PBL approach improved Saudi EFL students' speaking proficiency. Although the researcher had made homogenous sampling, comparisons were still made between the responses within the themes and across all themes to determine which responses corroborated or contradicted each other.

\section{RESULTS AND DISCUSSION}

\section{A. Results of Speaking Proficiency Test}

By the end of the experiment, the TSP was administered on the sample to test the first hypothesis of the study. This hypothesis predicted statistically significant differences between the mean scores of the experimental group and the control group on the post-application of TSP in favor of the experimental group. An independent-samples t-test was used to compare the mean scores of the experimental group and the control group on the post application of TSP. The results, displayed in Table 1, showed a statistically significant difference in the scores for the experimental group (M $=13.06, \mathrm{SD}=.691)$ and the control group $(\mathrm{M}=6.80, \mathrm{SD}=.961) ; \mathrm{t}(58)=28.985, \mathrm{p}=0.01$ in favor of the experimental group. These results showed a positive effect of the H-PBL approach on improving the students' speaking proficiency and the difference between the two groups is due to the implementation of the H-PBL.

TABLE 1.

INDEPENDENT-SAMPLES T-TEST RESULTS OF THE DIFFERENCES IN THE MEAN SCORES BETWEEN THE CONTROL GROUP AND THE EXPERIMENTAL GROUP ON THE POST APPLICATION OF TSP

\begin{tabular}{|c|c|c|c|c|c|c|}
\hline Group & $\mathrm{N}$ & Mean & Std. Deviation & $\mathrm{t}$ & $\mathrm{df}$ & Sig.(2-tailed) \\
\hline Control & 30 & 6.80 & .961 & & & \\
\hline Experimental & 30 & 13.06 & 691 & 28.985 & 58 & 0.01 \\
\hline
\end{tabular}

The experimental group students' speaking proficiency improvement in terms of fluency, pronunciation, vocabulary and grammar, as presented by their scores on each item compared to the students of the control group, is displayed in Table 2. The mean score of each item on the experimental group students' post-test is higher than that of the control group $(M=2.83>1.73$ for fluency; $M=2.80>1.66$ for pronunciation; $M=3.63>1.63$ for vocabulary; $M=3.80>1.76$ for grammar). Further analysis showed that the students improved mostly in grammar (M difference $=2.04)$ whereas fluency witnessed the less improvement $(\mathrm{M}$ difference $=1.10)$. Moreover, the results revealed that using $\mathrm{H}-\mathrm{PBL}$ resulted in a statistically significant improvement in all aspects of speaking proficiency.

TABLE 2.

INDEPENDENT-SAMPLES T-TEST RESULTS OF THE DIFFERENCES IN THE MEAN SCORES BETWEEN THE CONTROL GROUP AND THE EXPERIMENTAL GROUP ON THE POST APPLICATION OF TSP IN TERMS OF FLUENCY, PRONUNCIATION, VOCABULARY AND GRAMMAR

\begin{tabular}{|c|c|c|c|c|c|c|}
\hline \multirow[t]{2}{*}{ TBWS } & \multicolumn{2}{|c|}{ Control Group } & \multicolumn{2}{|c|}{ Experimental Group } & \multirow[b]{2}{*}{$t$} & \multirow[b]{2}{*}{$p$} \\
\hline & $M$ & $S D$ & $M$ & $S D$ & & \\
\hline Fluency & 1.73 & 0.44 & 2.83 & 0.37 & 10.24 & $0.01 *$ \\
\hline Pronunciation & 1.66 & 0.47 & 2.80 & 0.40 & 9.87 & $0.01 *$ \\
\hline Vocabulary & 1.63 & 0.49 & 3.63 & 0.49 & 15.80 & $0.01^{*}$ \\
\hline Grammar & 1.76 & 0.43 & 3.80 & 0.40 & 18.81 & $0.01^{*}$ \\
\hline
\end{tabular}

\section{B. Results of Students' Motivation Questionnaire}

The results of post application of SMQ showed that students of the experimental group were highly motivated compared to their counterparts of the control group. This confirmed the second hypothesis of the study that predicted statistically significant differences between the mean scores of the experimental group and the control group on the post-application of SMQ in favor of the experimental group. An independent-samples t-test was used to compare the mean scores of the experimental group and the control group on the post application of SMQ. The results, displayed in Table 3, showed a statistically significant difference in the mean scores of the experimental group $(\mathrm{M}=86.70, \mathrm{SD}=4.77)$ and the control group $(\mathrm{M}=33.30, \mathrm{SD}=4.77)$; $(58)=43.34, \mathrm{p}=0.01$ in favor of the experimental group. The results indicated a positive effect of the H-PBL approach on improving students' motivation.

TABLE 3.

INDEPENDENT-SAMPLES T-TEST RESULTS OF THE DIFFERENCES IN THE MEAN SCORES BETWEEN THE CONTROL GROUP AND THE EXPERIMENTAL GROUP IN POST APPLICATION OF SMQ

\begin{tabular}{|c|c|c|c|c|c|c|}
\hline Group & $\mathrm{N}$ & Mean & Std. Deviation & $\mathrm{t}$ & $\mathrm{df}$ & Sig.(2-tailed) \\
\hline Control & 30 & 33.30 & 4.77 & & & \\
\hline Experimental & 30 & 86.70 & 4.77 & 43.34 & 58 & 0.01 \\
\hline
\end{tabular}


Moreover, a positive correlation between the level of students' motivation and their improvement in speaking proficiency was found. Thus, it could be concluded that motivation is a prerequisite for a significant improvement in students' speaking proficiency.

The data analysis of students' oral presentations and subsequent interviews and a careful examination of the interviews transcripts by the instructors revealed three main findings (themes) and six secondary findings (sub-themes), corresponding to the variables identified in the research framework of this study. Figure 1 exhibits these main and secondary findings.

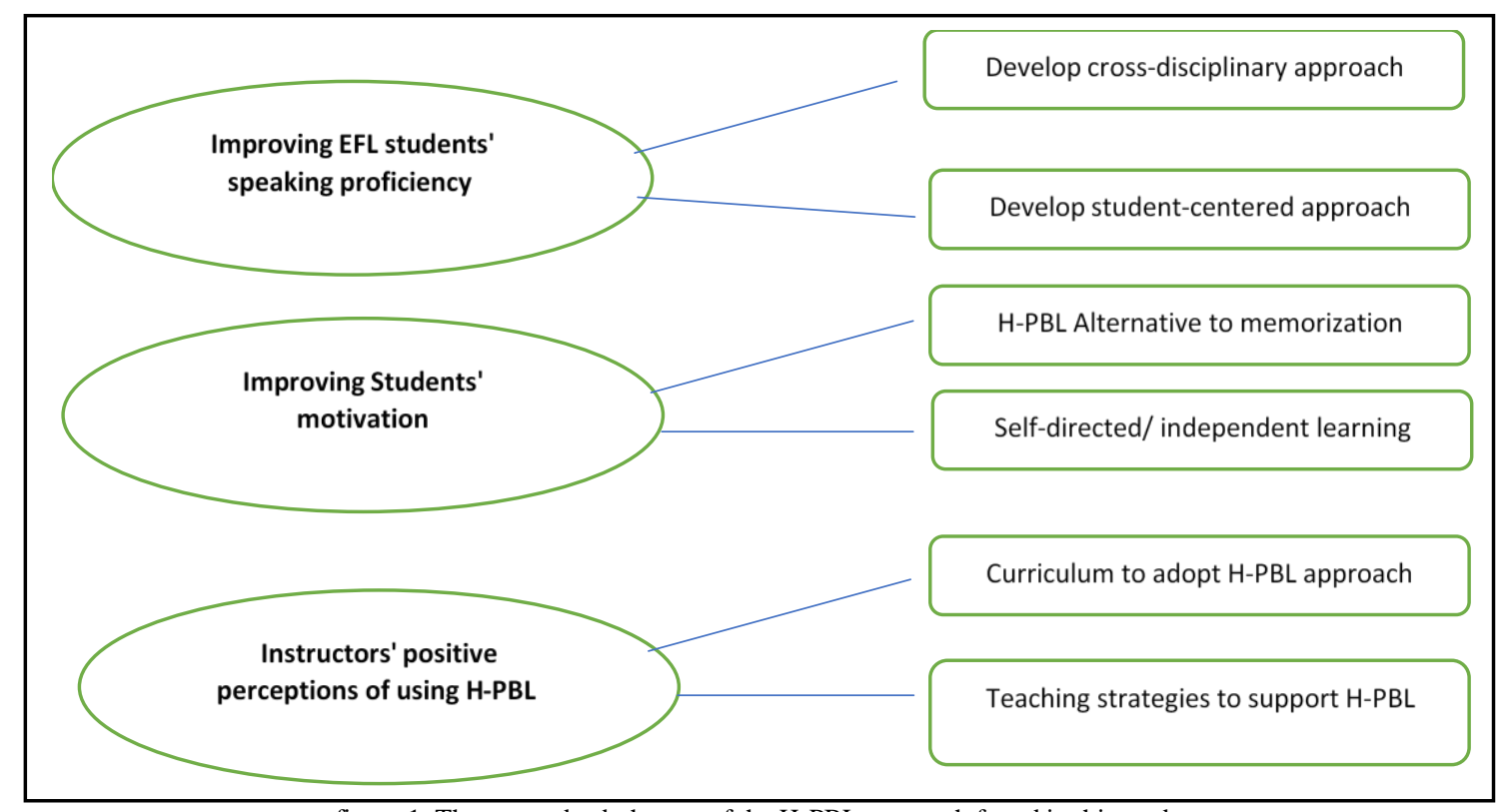

figure 1. Themes and sub themes of the H-PBL approach found in this study

As the figure reveals, the first major finding of introducing the H-PBL approach is improving EFL students' speaking proficiency. This was made possible mainly through two methods: a cross-disciplinary approach and a student-centered approach, which are ideally suitable for the H-PBL approach. The second set of findings of this study emerges in the form of improvement in students' motivation which was sub-divided into two categories for ease of understanding. That is, H-PBL is seen as an alternative to memorization or retention of learning and it encourages self-directed or independent learning to develop English speaking proficiency. The third cluster of findings was in the form of instructors' positive perceptions of the H-PBL approach with two sub-divisions: first, the curriculum must be adapted according to the new H-PBL learning and second, teaching strategies must support the H-PBL approach.

Students' motivation was explored when the students were asked whether they felt more motivated to learn speaking by using the new teaching approach, how far the new teaching technique suited their ability and which teaching approach they would prefer, the traditional lecture-based learning or the H-BPL. The main objective to ask such questions was to obtain information on how the H-PBL approach motivated participants for learning English and what was students' level of motivation for learning the Speaking course before and after implementing the H-PBL approach. Students admitted that in the beginning they faced multidisciplinary problems while trying to practice English speaking skills; e.g., they faced problems of memorization and retention but then the H-PBL was seen as an easy alternative. The researcher found that the H-PBL was referred to several times during the interviews, so it was acknowledged as the first sub-theme of motivation. Thus, many students admitted that H-PBL was the most convenient way to get rid of memorization habits and help in the retention of the lessons. Moreover, a few informants also mentioned that H-PBL helped them with self-directed learning. When H-PBL approach was employed, students could engage themselves in a learning process that improved their oral communication skills along with other activities such as analyzing and synthesizing the lectures. This was taken as the second sub-theme because H-PBL promoted self-directed learning and ensured the initiation of a lifelong learning process to.

\section{Results of Instructors' Interviews}

These interviews took place after the completion of the experiment. The purpose was to identify teachers' perceptions of the use of the H-PBL approach. Almost all interviewees accepted that H-PBL approach was definitely a useful approach but they emphasized that while using the H-PBL approach it was necessary to innovate without sacrificing the best of the traditional. According to them, prior to implementing the H-PBL approach, it was necessary to make two changes: first, to prepare a customized hybrid curriculum to adapt to the PBL approach and second, to identify the teaching strategies that support the H-PBL approach. The rationale for suggesting a hybrid curriculum of the speaking course was that it might encourage self-directed learning for the students and give enough opportunity to 
the teacher for discussing cross-disciplinary concepts. Thus, they admitted to what the student-informants had already commented on during their interviews. The instructors also emphasized that a revised curriculum of the speaking course would increase active learning and decrease students' passive learning or memorization that happened in the traditional method. For this purpose, the instructors suggested reducing the number of lectures from the traditional curriculum and introducing more tutorials, workshops and lab activities to ensure more interactive presentations. Their second suggestion related to identifying such teaching strategies that would support the H-PBL learning. The rationale for making this suggestion was that H-PBL approach involved teaching difficult concepts. In addition, the focus was also laid on getting the desired learning outcomes, making positive changes in learners' behavior, and developing speaking skills in particular. Hence, the instructors recommended identifying a range of carefully planned teaching strategies for integrating all pedagogical elements required for the PBL approach. These findings are consistent with those of previous studies (e.g., Distlehorst et al 2005; Huang, 2012; Li, 2013).

\section{CONCLUSION}

This study posits a few interesting facts about H-PBL approach. First, it was revealed that H-PBL, if used in a discipline-specific situation such as teaching a speaking course, would prove to be a good initiative for introducing this new teaching approach. Second, in a problem-based approach, students address the problem without any prior preparation which interestingly motivates them. The problem may be presented to them as a complex, very illstructured, challenging and pragmatic one. But it was observed that students are able to discuss and analyze the problem to determine and locate the resources to solve it. Thus, they develop their skills independently in a self-directed way, either individually or in a group. Eventually, students develop a sense of responsibility for their own learning and they work independently of one another. The researcher concluded that the H-PBL approach proved to be an effective way to improve EFL students' speaking proficiency and motivation.

The present study had certain limitations too. First, the generalization of the findings may not be applicable to all skills courses as this research was conducted only in the context of a speaking course in the undergraduate program of PSAU, Saudi Arabia. Second, the data were collected from a very small sample size, confined to PSAU's English Department. It would have been more credible if the study sample was collected from 4 or 5 different universities around Saudi Arabia and also from two concurrent academic semesters to determine its vast application, transferability and application beyond time measurements. Factors such as gender, age, educational backgrounds and level of language comprehension represent another limitation of this study. These factors were not explored in this study as they were outside its scope of investigation but can be investigated and explored in further research.

Two main challenges faced the researcher in carrying out the present study. Changing students' learning style and perceptions of the learning process represented the first challenge. Students, under the conventional method of teaching, expected to receive the learning material from the teacher without any real participation or serious efforts. Thus, encouraging students to be involved in problem-solving was not an easy task. Gradually, students succeeded in adjusting themselves to learn, act and work collaboratively according to the new conditions. Changing the instructor's role from transmitter to mentor/coach represented the second challenge as many difficulties arose: developing the instructor's coaching skills, redesigning the content of the course to match the requirements of H-PBL, tailoring immediate feedback on students' progress and crafting evaluating tasks.

This study has wider perspectives as the H-PBL approach could be applied to other areas of language learning. Future studies should be carried out to explore the possibility of applying the H-PBL approach to other skills and courses such as reading, writing, grammar and vocabulary. Eventually, faculty development programs and workshops are recommended to train instructors on how H-PBL approach could be implemented successfully.

ApPendix A. SPEAKING PROFICIENCY GRAding Rubric

\begin{tabular}{|l|l|l|l|l|}
\hline Aspect/Criterion & 1 Poor & 2 Satisfactory & 3 Good & Excellent \\
\hline Fluency & $\begin{array}{l}\text { Students speak very slowly, } \\
\text { pauses are frequent and } \\
\text { lengthy, breakdowns are } \\
\text { detected and hesitation } \\
\text { impedes possible } \\
\text { communication. }\end{array}$ & $\begin{array}{l}\text { Students are often slow } \\
\text { and incomplete } \\
\text { sentences are used. } \\
\text { However, students are } \\
\text { able to process the } \\
\text { speech. }\end{array}$ & $\begin{array}{l}\text { Students' speech is almost } \\
\text { smooth. However, some } \\
\text { hesitation and repetition } \\
\text { may take place with little } \\
\text { effect on the } \\
\text { comprehensibility. }\end{array}$ & $\begin{array}{l}\text { Students speak fluently and } \\
\text { smoothly. They are able to } \\
\text { appropriately. Hesitation and } \\
\text { reluctance are avoided. }\end{array}$ \\
\hline Pronunciation & $\begin{array}{l}\text { Students lack the right } \\
\text { pronunciation rules. No } \\
\text { efforts are detected to use the } \\
\text { right accent. Understanding } \\
\text { is hard to be achieved. }\end{array}$ & $\begin{array}{l}\text { Students commit } \\
\text { frequent pronunciation } \\
\text { errors and create some } \\
\text { difficulty to the listener. }\end{array}$ & $\begin{array}{l}\text { Students commit some } \\
\text { pronunciation, inflection, } \\
\text { rhythm and intonation } \\
\text { errors. However, these } \\
\text { minor errors do not create } \\
\text { misunderstanding. }\end{array}$ & $\begin{array}{l}\text { Students use the right } \\
\text { pronunciations, inflection, } \\
\text { rhythm and intonation. They } \\
\text { use a native like accent. }\end{array}$ \\
\hline Vocabulary & $\begin{array}{l}\text { Students are unable to use } \\
\text { suitable words to express } \\
\text { their ideas. Lack the } \\
\text { appropriate vocabulary } \\
\text { impedes them from } \\
\text { producing the right response. }\end{array}$ & $\begin{array}{l}\text { Students use } \\
\text { basic/limited vocabulary } \\
\text { choice as variety and } \\
\text { richness are lacking. }\end{array}$ & $\begin{array}{l}\text { Students use accurate } \\
\text { vocabulary. Repetition of } \\
\text { some words may be } \\
\text { detected. Students are still } \\
\text { able to express their ideas } \\
\text { clearly. }\end{array}$ & $\begin{array}{l}\text { Students use rich and precise } \\
\text { vocabulary to express their } \\
\text { ideas eloquently. Idiomatic } \\
\text { language is used accurately to } \\
\text { enrich their speech. }\end{array}$ \\
\hline
\end{tabular}




\begin{tabular}{|l|l|l|l|l|}
\hline Grammar & $\begin{array}{l}\text { Students are unable to use } \\
\text { correct grammatical rules and } \\
\text { are hard to be understood by } \\
\text { others as mistakes impede } \\
\text { communication. }\end{array}$ & $\begin{array}{l}\text { Students commit many } \\
\text { mistakes that they are } \\
\text { unable to correct, fail to } \\
\text { use varied sentence } \\
\text { structures and accurate } \\
\text { tenses, and }\end{array}$ & $\begin{array}{l}\begin{array}{l}\text { Students commit some } \\
\text { mistakes. However, they are } \\
\text { able to correct themselves } \\
\text { and this does not negatively } \\
\text { affect the comprehensibility } \\
\text { of their speech }\end{array} \\
\text { grammatical rules. They use } \\
\text { varied sentence structures and } \\
\text { accurate tenses. }\end{array}$ \\
\hline
\end{tabular}

\section{Appendix B. Students' Motivation Questionnaire}

Read the following statements and choose the number that best matches your opinion of each statement. 1. Strongly disagree 2. Slightly disagree 3. Neutral (Neither agree nor disagree) 4. Slightly agree 5. Strongly agree

\begin{tabular}{|c|c|c|c|c|c|}
\hline Statement & 1 & 2 & 3 & 4 & 5 \\
\hline \multicolumn{6}{|l|}{ 1. English is my most favorite subject } \\
\hline \multicolumn{6}{|l|}{ 2. I persist in using English even if I face difficulties } \\
\hline \multicolumn{6}{|l|}{ 3. I exert much effort to be fluent in English } \\
\hline \multicolumn{6}{|l|}{ 4. Learning English inspires me } \\
\hline \multicolumn{6}{|l|}{ 5. I plan to improve my English language skills } \\
\hline \multicolumn{6}{|l|}{ 6. Attending English classes is really great } \\
\hline \multicolumn{6}{|l|}{ 7. I like listening to people speaking English } \\
\hline \multicolumn{6}{|l|}{ 8. I try to speak English for the praise of the instructor. } \\
\hline \multicolumn{6}{|l|}{ 9. I like reading English articles and watching English movies } \\
\hline \multicolumn{6}{|l|}{ 10. Communicating with English native speakers is interesting. } \\
\hline \multicolumn{6}{|l|}{ 11. I study English diligently as it will help me to get a good job after graduation. } \\
\hline \multicolumn{6}{|l|}{$\begin{array}{l}\text { 12. I study English diligently to prepare myself for higher studies after } \\
\text { graduation. }\end{array}$} \\
\hline \multicolumn{6}{|l|}{ 13. I'm more confident in using English compared to my colleagues. } \\
\hline \multicolumn{6}{|l|}{ 14. I like to learn more about different aspects of English language } \\
\hline \multicolumn{6}{|l|}{ 15. I do my best to understand oral and written English } \\
\hline \multicolumn{6}{|l|}{ 16. If it is my decision, I would devote more time for studying English } \\
\hline \multicolumn{6}{|l|}{ 17. Studying English contributes positively to my personal development } \\
\hline \multicolumn{6}{|l|}{ 18. English is a major component of the College program } \\
\hline \multicolumn{6}{|l|}{ 19. I plan to attend more English classes in the future } \\
\hline $\begin{array}{l}\text { 20. Conducting some mistakes while using English does not impede me from } \\
\text { communicating with others in English }\end{array}$ & & & & & \\
\hline
\end{tabular}

\section{APPENDIX C. STUDENTS' AND INSTRUCTORS' INTERVIEWS}

\section{Students' Interview}

1. Did the new approach employed in the course motivate you?

2. How and when did you and your group members get motivated -during discussions, reading for the text, speaking?

3. Are you still motivated to continue your learning skills even after the completion of this class?

4. Do you think that the assigned learning goals have been achieved with this new teaching approach?

5. Did this class address your learning needs and learning outcomes?

6. Do you prefer the old teaching approach or the new one? And why?

7. What do you think is required to become a good speaker in English?

8. In what way has the new teaching approach improved your speaking proficiency?

9. Do you think the new approach will affect your performance in class (e.g higher GPA)

10. Do you think the new approach can be employed to study other courses as well e.g Reading and Writing, Grammar and Vocabulary?

\section{Instructors' Interview}

1. Which teaching approach do you prefer the traditional teaching approach or the H-PBL? Why?

2. Do you think that H-PBL suits the students' ability?

3. Do you think that students became more motivated to learn English in the new teaching approach that you applied this semester?

4. Do you think that students' speaking proficiency improved as a result of implementing the new teaching approach?

5. Do you recommend this approach to teach the speaking course in EFL at Prince Sattam bin Abdulaziz University?

6. Do you think the text books are adequately designed to suit the H-PBL approach?

7. Do you think the current curriculum and credit system adequately designed to suit the H- PBL approach?

8. Do you think the instructors are adequately trained to adopt the H-PBL approach in their teaching?

9. How much time do you think will be required for the students to completely switch over to the new teaching technique?

10. What are the advantages and challenges of using the H-PBL approach in the context of this university? 


\section{APPENDIX D. SAMPle H-PBL LESSON Plan}

\begin{tabular}{|c|c|c|c|}
\hline Stage & Content & Teaching/Learning Activities & Teaching/ Learning Outcomes \\
\hline Stage 1 & $\begin{array}{l}\text { - Speaking Course overview } \\
\text { - PBL introduction } \\
\text { - Accent/ Pronunciation orientation } \\
\text { - Group formation }\end{array}$ & $\begin{array}{l}\text { - Pronunciation, Accent etc. samples taken } \\
\text { of students to determine their current level of } \\
\text { performance (Peer/ group discussions) }\end{array}$ & $\begin{array}{l}\text { - Great academic environment built } \\
\text { up to implement PBL approach } \\
\text { - Problems identified }\end{array}$ \\
\hline Stage 2 & $\begin{array}{l}\text { - Recall of Problems identified in the } \\
\text { last stage } \\
\text { - Instructor draws a table consisting of } \\
\text { four columns: (1) Facts (2) Problems } \\
\text { (3) Hypotheses about cause and effect } \\
\text { and (4) Learning objectives. }\end{array}$ & $\begin{array}{l}\text { - learning objectives explained; focus to be } \\
\text { on PBL approach } \\
\text { - Instructors discusses facts / problems/ } \\
\text { various causes and effect ( e.g Cultural } \\
\text { barriers; words meanings; Hesitation; Fear of } \\
\text { failure }\end{array}$ & $\begin{array}{l}\text { - Engagement and Task focus; } \\
\text { - Learning starts: Pronunciation and } \\
\text { accent clarity encouraged; Loud and } \\
\text { clear reading, Problems understood } \\
\text { - Schematic representation of } \\
\text { problems \& their explanation }\end{array}$ \\
\hline Stage 3 & $\begin{array}{l}\text { - Group discussions of problem and } \\
\text { methods used to solve it. } \\
\text { - students encouraged to speak their } \\
\text { mind }\end{array}$ & $\begin{array}{l}\text { - Group contributes their views and thoughts } \\
\text { to problems identified. } \\
\text { - Students raise relevant points from their } \\
\text { prior knowledge to explain the problem, }\end{array}$ & $\begin{array}{l}\text { - students motivated, interest and } \\
\text { curiosity stimulated } \\
\text { - students made to think deeply rather } \\
\text { than just memorize } \\
\text { - a framework designed to initiate the } \\
\text { teaching based on PBL approach }\end{array}$ \\
\hline Stage 4 & $\begin{array}{l}\text { - Students need to acquire necessary } \\
\text { knowledge about learning outcomes } \\
\text { before course commencement. }\end{array}$ & $\begin{array}{l}\text { - Group agree on a set of focused and } \\
\text { achievable learning outcomes. } \\
\text { - Self-directed learning; private study and } \\
\text { use of a wide range of resources } \\
\text { Each student practiced to understand what } \\
\text { work is to be done to achieve learning } \\
\text { outcomes }\end{array}$ & $\begin{array}{l}\text { - Restructuring prior and existing } \\
\text { knowledge to identify gaps in } \\
\text { understanding, } \\
\text { - concepts are linked and priority } \\
\text { areas identified. } \\
\text { - students motivated to learn from } \\
\text { several resources }\end{array}$ \\
\hline $\begin{array}{l}\text { Stage } 5 \\
\text { Classroom } \\
\text { teaching } \\
\text { begins) }\end{array}$ & $\begin{array}{l}\text { - Real learning begins with H-PBL } \\
\text { approach } \\
\text { - Text based study focused on } \\
\text { developing Speaking skills, } \\
\text { pronunciation etc }\end{array}$ & $\begin{array}{l}\text { - Students listened to the audios and teacher } \\
\text { explained correct articulation of consonants, } \\
\text { vowels, diphthongs, etc. } \\
\text { - Students practiced the articulation of the } \\
\text { words Students used some variety in their } \\
\text { voice (volume, rate, pitch, and rhythm, use } \\
\text { stress and intonation) they emphasized key } \\
\text { words (noun, verbs, adjectives and adverbs). }\end{array}$ & $\begin{array}{l}\text { - Students were able to produce a } \\
\text { stretch of spoken discourse that was } \\
\text { grammatically correct } \\
\text { - They assisted each other in } \\
\text { understanding difficult concepts. } \\
\text { - Critical reflection on the techniques } \\
\text { achieved } \\
\text { - Self-discipline and criticizing } \\
\text { resources done }\end{array}$ \\
\hline
\end{tabular}

\section{REFERENCES}

[1] Ahlfeldt, S. (2003). Problem-based learning in the public speaking classroom. Ph.D. dissertation, North Dakota State University.

[2] Alajmi, N. (2014). Factors that influence performance in a problem-based learning tutorial. Ph.D. dissertation, Bond University.

[3] Alfawzan, M. (2012). Saudi students' attitude towards the utility of English and their willingness to learn it. Unpublished Master's thesis, Southern Illinois University, Carbondale, IL.

[4] AlKaabi, A. (2016). Saudi students' motivation and attitudes toward learning English as a second language and their willingness to invest in learning it. Unpublished Master's thesis, St. Cloud State University.

[5] Amma, C. (2005). Effectiveness of computer-based mind maps in the learning of Biology at the higher secondary level. New Delhi: ICDE International Conference (November, 19-23).

[6] Armstrong, E. G. (1991). A hybrid model of problem-based learning. In D. Boud \& G. Feletti (eds.). The challenge of problembased learning ( $2^{\text {nd }}$ edition). London: Kogan page.

[7] Aslam, Z. (2014). A study of factors responsible for low motivation level for learning English as second language level in Saudi female students. Journal of English Language and Literature, 1(1), 8-12.

[8] Barrell, J. (2007). Problem-based learning: An inquiry approach. California, US. Corwin Press.

[9] Barrows, H. S. (1986). How to design a problem-based curriculum for the preclinical years. New York: Springer Publishing Company, Inc.

[10] Ben-Ari, M. (2001). Constructivism in computer science education. Journal of Computers in Mathematics and Science Teaching, 20(1), 45-73.

[11] Bridges, E. \& Hallinger, P. (1992). Problem-based learning for administrators. Eugene: ERIC Clearinghouse on Educational Management, University of Oregon.

[12] Bueno, P. (2016). Critical thinking skills in a hybrid PBL approach. Paper presented at the $9^{\text {th }}$ Annual International Conference of Education, Research and Innovation (November, 14-16, Seville, Spain).

[13] Bueno, P., Rivas, S. \& Saiz, C. (2015). Critical thinking assessment with PENCRISAL test in a hybrid approach to PBL. In E.de Graaff, A. Guerra, A. Kolmos \& N. A. Arexolaleiba (Eds.), Global Research Community: Collaboration and Developments (pp. 213-222). Denmark: Aalborg Universitetsforlag.

[14] Creswell, J.W. (2014). Research design: Qualitative, quantitative and mixed methods approaches, (4 ${ }^{\text {th }}$ edition), California: Sage Publications.

[15] Deci, E.L., \& Ryan R.M. (2002). Handbook of self-determination research. Rochester, New York: University of Rochester Press.

[16] Distlehorst, L. H., Dawson, E., Robbs, R. S., \& Barrows, H. S. (2005). Problem-based learning outcomes: The glass half-full. Academic Medicine, 80, 294-299. 
[17] Doody, J. (2015). An evaluation of the effectiveness of using a hybrid PBL approach in the teaching of the Java programming language to first year third level. Higher Education in Transformation Conference, Dublin, Ireland, 159-173.

[18] Dornyei, Z. (2007). Research methods in applied linguistics. New York: Oxford University press.

[19] Dornyei, Z. (2008). Motivation and motivating in the foreign language classroom. The Modern Language Journal, 78(3), 273284.

[20] Gijbels, D. \& Loyens, S. (2009). Constructivist learning (environments) and how to avoid another tower of Babel: Reply to Renkl. Instructional Science, 37(5), 499-502.

[21] Glaser, B \& Strauss A. (2006). The discovery of grounded theory: Strategies for qualitative research. Aldine Transaction: New Brunswick, US.

[22] Glover, P. (2011). Using CEFR level descriptors to raise university students' awareness of speaking skills. Language Awareness, 20(2), 121-133, DOI: 10.1080/09658416.2011.555556.

[23] Guba, E. \& Lincoln, Y. (1989). Fourth generation evaluation. Newbury Park, CA: Sage.

[24] Hmelo, C. E., Gotterer, G. S., \& Bransford, J. D. (1994). The cognitive effects of problem-based learning: A preliminary study. Paper presented at the Annual Meeting of the American Educational Research Association, New Orleans, LA.

[25] Huang, K. (2012). A Study on the incorporation of problem-based learning (PBL) in a university freshman English class. The Journal of International Management Studies, 7(2), 125-134.

[26] Jaleniauskiene, E. (2016) Revitalizing foreign language learning in higher education using a PBL Curriculum. International Conference on Teaching and Learning English as an Additional Language, Glob ELT (April, 14-17, Antalya, Turkey).

[27] Jonassen, D. (2011). Learning to solve problems: A handbook for designing problem-solving learning environments. NY and London: Routledge.

[28] Juvova, A., Chudy, S., Neumeister, P. Plischke, J. \& Kvintova, J. (2015). Reflection of constructivist theories in current educational practice. Universal Journal of Educational Research, 3(5), 345-349.

[29] Larsson, J. (2001). Problem-based learning: A possible approach to language education? Polonian Institute, Jagiellonian University.

[30] Li, D. (2013). Facilitating motivation: Implementing problem-based learning into the science classroom. Master's thesis, State University of New York.

[31] Lian, J. \& He, F. (2013). Improved performance of students instructed in a hybrid PBL format. Biochemistry and Molecular Biology Education, 41(1), 5-10.

[32] Liang, L. \& Gabel, D. (2005). Effectiveness of a constructivist approach to science instruction for prospective elementary teachers. International Journal of Science Education, 27(10), 1143-1162.

[33] Gilbert, L. (2011). Going the distance: "Closeness" in qualitative data analysis software. International Journal of Social Research Methodology, 5(3), 215-228, DOI: 10.1080/13645570210146276.

[34] Miles, M., Huberman, M. \& Saldana, J. (1994). Qualitative data analysis: A methods sourcebook, (3rd Edition). California: Sage Publications.

[35] Mossuto, M. (2009). Problem-based learning: Student engagement, learning and contextualized problem-solving. Occasional Paper. ERIC Reproduction Center ED No. 507339.

[36] Murphy, P. \& Alexander, P. (2000). A motivated exploration of motivation terminology. Contemporary Educational Psychology, 25(1), 3-53. http://dx.doi.org/10.1006/ceps.1999.1019.

[37] Neo, M. \& Neo, T. (2009). Engaging students in multimedia-mediated constructivist learning - Students' perceptions. Journal of Educational Technology \& Society, 12(2), 254-266.

[38] Norman, G. \& Schmidt, H. (1992). The psychological basis of problem-based learning: A review of evidence. Academic Medicine, 67(9), 557-565.

[39] Onwuegbuzie, A., Leech, N., Slate, J., Stark, M., Sharma, B., Frels, R. \& Combs, J. (2012). An exemplar for teaching and learning qualitative research. The Qualitative Report, 17(1), 16-77.

[40] Razzak, N. (2012). Problem-based learning in the educational psychology classroom: Bahraini teacher candidates' experience. International Journal of Teaching and Learning in Higher Education, 24(2), 134-143.

[41] Rohim, A. (2014). Improving students' speaking skill through problem-based learning (PBL) strategy. JP3, 3(8), 1-7.

[42] Rosalina, E. (2013). Improving students' speaking skill by implementing problem-based learning (PBL). MA thesis, Sebelas Maret University.

[43] Savery, J. (2006). Overview of problem-based learning: Definitions and distinctions. Interdisciplinary Journal of ProblemBased Learning, 1(1), 9-20.

[44] Shabani, M. (2013). The effect of background knowledge on speaking ability of Iranian EFL learners. Language, 1(1), 25-33.

[45] Strauss, A \& Corbin, J. (1994). Grounded theory methodology: An overview. In N. K. Denzin \& Y. S. Lincoln (Eds.), Handbook of qualitative research (pp. 273-285). Thousand Oaks, CA, US: Sage Publications.

[46] Taber, K. (2000). Chemistry lessons for universities?: A review of constructivist ideas. University Chemistry Education, 4(2), 63-72.

[47] Teddlie, C. \& Tashakkori, A. (2008). Foundations of mixed methods research: Integrating quantitative and qualitative approaches in the social and behavioural sciences. Thousand Oaks, CA: Sage Publications.

[48] Trop, L. \& Sage, S. (2002). Problems as possibilities: Problem-based learning for k-16 education. ( $2^{\text {nd }}$ edition), ASCD, Alexandria, VA.

[49] Uden, L. \& Beaumont, C. (2006). Technology and problem-based learning. Hershey: PA: Information Science Publishing.

[50] Wang, F. (2008). Motivation and English achievement: An exploratory and confirmatory factor analysis of a new measure for Chinese students of English learning. North American Journal of Psychology, 10(3), 633-646.

[51] Wu, Y. (2006). Applying a hybrid problem-based learning method to the teaching of computer programming. The China Papers, November, 63-66.

[52] Yin, R. (2014). Case study research: Designs and methods (5th ed.). Thousand Oaks, CA: Sage Publications. 
Mohamed A. Kassem is a faculty member at the Department of Curriculum and Teaching Methodology, New Valley College of Education, Assiut University, Egypt. He earned his PhD in TEFL in 2011. He is highly interested in several areas: improving EFL learners' language skills, using technology to create a supporting learning environment and using alternative assessment techniques. 